\title{
Maritime Boundaries and Sir Creek Dispute: Re-Appraising India's Options
}

\author{
Cmde SL Deshmukh NM (Retd)* and Dr R Srinivasan**
}

\begin{abstract}
The pre-eminence of maritime power is very well illustrated by history of the contemporary world. Importance of the Exclusive Economic Zones (EEZs) for national economies and as a result, global race to claim and control various parts of oceans/seas has become intense over the years. In view of the current geo-political scenarios, adherence to the existing international laws- related to seas and economic zones codified in the form of UNCLOS has become necessary to resolve issues related to maritime boundaries and their protection.
\end{abstract}

India appreciates importance of UNCLOS and has been trying to lawfully resolve its long pending maritime dispute with Pakistan, albeit with limited success. For India, the Sir Creek area would always be of strategic importance in view of its national security and economic well-being. There is ample historical evidence in support of India claims in Sir Creek. There are also many scholarly studies that have examined this boundary issue with a view to find solutions within the ambit of UNCLOS.

This paper traces the concept of maritime boundaries and some of the important scholarly solutions for resolving the Sir Creek dispute. It also examines the emerging geopolitical scenarios in the Arabian Sea and finds that a sense of urgency is attached to finding an early and amicable solution to the issue. Keeping these factors in mind, this paper also suggests actions needed to be taken by India to protect its economic and security interests.

Keywords: Maritime Boundaries, Sir Creek, India, Pakistan, UNCLOS, dispute resolution, geopolitics

* Cmde SL Deshmukh NM (Retd) is Vice President, Sun Group, and researches independently on strategic affairs.

** Dr R Srinivasan is a former Group Captain, Indian Air Force, and is an independent researcher. 


\section{Maritime Boundaries and Sir Creek Dispute: Re-Appraising India's Options}

\section{Introduction}

India inherited its maritime boundaries in the same context in which it gained its independence - partition of the subcontinent in 1947. Among its maritime neighbours were Pakistan and Sri Lanka with Myanmar and Malaysia spaced a little far away to be of immediate concern. The partition and accession of Kashmir to India brought India and Pakistan engage in armed conflicts. Barring Siachen Glacier and the Pak Occupied Kashmir (PoK), the otherwise hastily drawn Radcliffe Line has never been in question in the dispute in so far as land borders were concerned. Even the creation of Bangladesh in 1971 did not result in conflicts over land boundaries. However, on the sea, the narrow 60 mile boundary known as Sir Creek connecting the southern Sindh Province of Pakistan and Indian state of Gujarat has remained an unresolved issue between both the countries for over a century now, predating even their independence.

India and Pakistan are both signatories to the 1982 UNCLOS. India specially had shown remarkable initiative in resolving its maritime boundary questions with Sri Lanka and Bangladesh through reconciliation and arbitration in the true spirit of UNCLOS. However, despite plethora of Confidence Building Measures (CBM) and dialogues between India and Pakistan, Sir Creek has remained outside any settlement.

The issue of Sir Creek is not merely a question of settling borders. It also involves the livelihood of fishermen from Sindh and Gujarat since the creek area is abundant with fish. It is also the subject of expert dialogues, scholarly studies and international arbitrations. Scholarly opinions even look at it as a potential source through which the apparently irreconcilable Indo-Pak difference could be converged for greater stability in South Asia. Thus understanding Sir Creek issue with a view to find mechanisms to resolve it bilaterally gains importance.

With an UNCLOS framework available for understanding maritime borders, along with appropriate case laws, it can also be stated that vague and baseless presumptions can be set aside to understand the issue conceptually first. It would then be possible to analyse Sir Creek issue with a view to arrive at possible solutions. The urgency to do so over a century old phenomena, especially for India, arrives from the geopolitical contexts that are emerging in the Indo-Pacific. 
This paper first attempts to explore the concept of maritime boundaries within the provisions of UNCLOS. It then deals with Sir Creek with a view to evolve possible frameworks for resolving the issue. It also points to the emerging geopolitical context which lends a sense of expediency to India to have this resolved.

\section{Part I: Evolution on the Concept of Maritime Boundary Lines}

With increase in world population, stressed land based natural resources, food shortages and energy security concerns, nations have turned toward oceans and seas to fulfil their needs and in some cases their greed. This has given rise to maritime boundary disputes and tensions amongst the nations. To resolve such discords, United Nations came up with concept of Maritime Boundaries of nations.

The United Nations Convention on Laws of the Sea (UNCLOS) is a powerful instrument to deal with peaceful operations in maritime domain. UNCLOS generally defines the rights and responsibilities of nations with respect to their use of the world's oceans. As Guo (Guo, 2018a) states: "It propagates guidelines for businesses, the environment and the management of marine natural resources..." The UNCLOS has also defined various yardsticks to measure maritime boundaries. For example, it defines a baseline as the line from which the seaward limits of a state's territorial sea and certain other maritime zones of jurisdiction should be measured. Under the UNCLOS, a sea baseline follows the low-water line of a coastal state. The following methods have been suggested to measure a baseline (Fig: 1):

Fig 1: Suggested methods for measuring Base Line

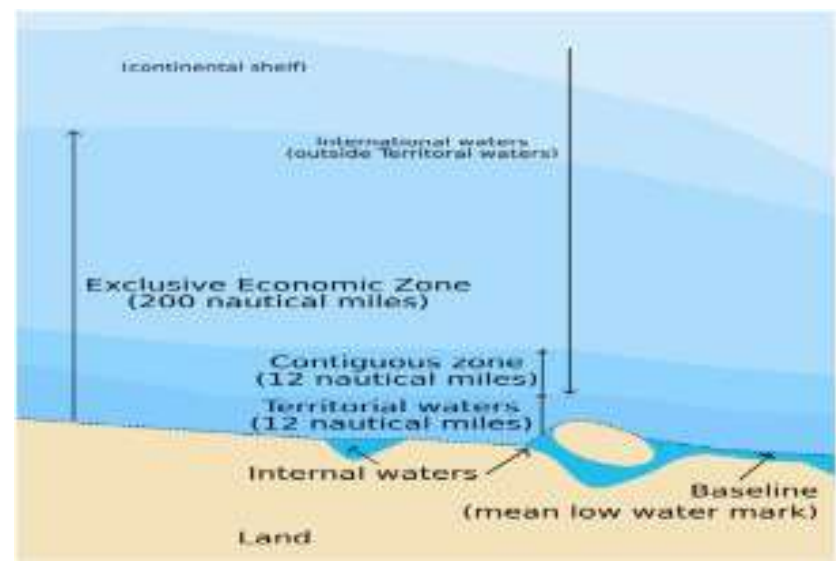

Source: Historicair Apr 22.2006 


\section{Complexities involved in Marking of Base Lines and Maritime Boundaries}

Though the above mentioned concepts of marking the base line seem simple and straight forward, in reality they are far from being so. The Scholars from Tufts University (TFS, 2017) point out that, "Although it is easy to determine how baselines can be drawn from large areas of continental coastline, such as in Florida or California, there are other maritime features that can affect how zones are drawn." These include:

- Straight baselines (which are not a feature, but change the baseline when used)

- $\quad$ River Mouths

- Bays

- $\quad$ Islands

- Rocks

- $\quad$ Reefs and Atoll

- $\quad$ Low-Tide Elevations

- $\quad$ Artificial Islands, Installations, and Structures

Though maritime features and zones are defined in the Laws of Sea Convention (LOSC), these features and zones are prone to environmental factors like rising sea levels, appearance and disappearance of reefs and rocks due to climate change and even man made features like those witnessed in South China Sea. It is but natural that the perceptions over them by the littoral nations also change over time. Nature induced or manmade, the changes to marine features therefore have resulted in controversies across the world. The effects of maritime features and controversies they may lead to have been well explained in the TFS Narrative (TFS, n.d). The example of the Gulf of Sidra given in the narrative has some similarities with Sir Creek dispute:

The controversy over the Gulf of Sidra (Fig: 2), for example, illustrates the challenges posed by bays and straight baselines. Located between the eastern and western halves of Libya, the Libyan government under Muammar Gadhafi in the 1970s had attempted to draw a straight baseline across the Gulf of Sidra and declare it as internal waters. 
Fig: 2 Libya's Claim to the Gulf of Sidra

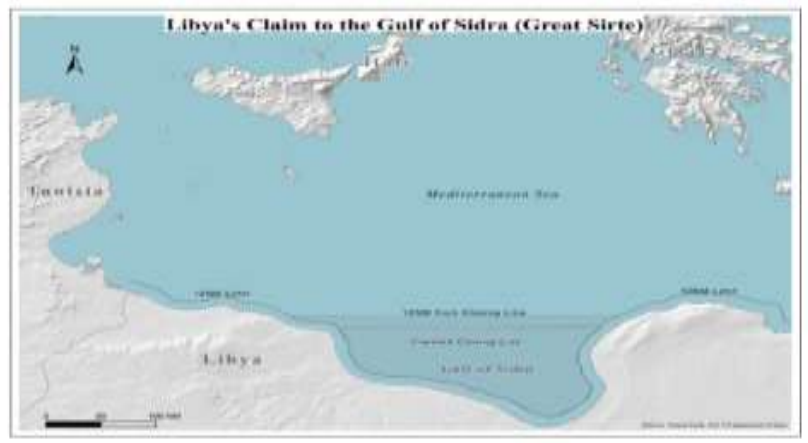

Image Source: Tufts University at https://sites.tufts.edu/lawofthesea/chapter-two/

This would have allowed Libya a much larger area to restrict navigation and overflight. Most nations did not recognize the claim because, under the LOSC, the baseline did not conform to the shape of the coast. These nations also opposed Libya's claim to historical use, due to a lack of demonstrated usage and its large size.

Similar problem has become a hindrance in settlement of Sir Creek dispute.

It is also important to recognize that current demarcation of maritime zones are affected changing sea levels caused by shift in the rivers and creeks discharging at specific locations. Change of course of rivers or creeks through natural or manmade activities like building of dams upstream are known to effect such changes. In the process of such changes, rocks and low tide elevations expand or contract due to tidal conditions. These affect EEZ control of the littoral nations. The LOSC unfortunately provides no clear guidance on this controversial issue. Later we will see how this phenomenon has afflicted the Sir Creek issue.

\section{Understanding Maritime boundary disputes}

History would reveal that the sea has been used by many nations to further their political and economic interests. However, the economic interests of various nations that have assumed primacy since late 1990s through globalization, coupled with their legitimate aspirations for prosperity through trade, have brought the oceans into a sharp focus. The 'Gun Boat Diplomacy' prevalent in $17^{\text {th }}$ to $19^{\text {th }}$ centuries gradually moved towards creating international norms for use of the sea and its resources. In this context Osthagen (Osthagen, 2020a) rightly observes that: 
When states legalized the maritime domain in the 20th century, the relationship between states and maritime space changed. Since the turn of the millennium, certain global trends have further amplified the role of the oceans in international affairs. This has led to a renewed focus on maritime space, as well as states' rights and responsibilities within that domain, delineated through the concept of a 'boundary' at sea.

Considering that the value of the global ocean-based economy has been estimated between USD 3-6 trillion/year and more than 3 billion people rely on the oceans for their livelihoods (UNCTAD, n.d), it would be easy to understand importance of the maritime zones. Analysts like Hasan, et.al, (Hasan, Jian, Alam \& Chowdhury, 2019) observed that in most of the cases, the maritime boundary dispute occurs due to the overlapping claims in different maritime zones and the contesting claims of sovereignty over the islands. With increasing populations and the resultant priority to obtain economic development, apart from anticipated material gains from the sea wealth, many nations have gone into disputes over their maritime boundaries. The Sir Creek dispute also has its origins in the above described phenomenon.

\section{Mechanisms for Resolution of Maritime Boundary Disputes}

At this juncture it would be prudent to briefly focus on globally accepted dispute resolution methodologies. As Guo (Guo 2018b) observed, historically successful settlement of territorial disputes and resource management in cross-border areas has not been easy as various obstacles and challenges have been encountered. In his discourse on Cross-Border Conflict Prevention and Management Guo stated:

Five major conflict prevention mechanisms or techniques namely negotiation, mediation, arbitration, litigation and shelving disputes strategy were propagated and four functional zones like buffer zone, neutral zone, demilitarized zone and international peace park were designed for areas in conflict, to maintain peace. However, it was up to the nations to follow these conventions.

Though these guiding principles related to drawing of maritime boundaries have been generally accepted, interestingly states adopt different ways for settling maritime boundary disputes. In practice, states may manage to agree on boundary disputes, agree on a mutual solution after bilateral negotiations or after having attempted to negotiate in good faith, submit the case for 
adjudication at the ICJ or another international Court like ITLOS (International Tribunal for the Law of the Sea) or they may use third-party arbitration like the Permanent Court of Arbitration (PCA).

Lately, Osthagen (2020b) finds that, "owing to the need for compromise, disputes have been generally settled through bilateral negotiations, avoiding referrals to international courts. It has also been seen that some nations have settled their maritime boundary disputes by mutually agreeing to delimitation of the boundaries". A classic example for negotiated settlement of maritime disputes in South Asia, perhaps unique in the world, is that of India and Sri Lanka over Kachathivu Island. In 1974 India and Sri Lanka signed an agreement which was further fortified in 1976 after which India formally recognized the Island as Sri Lankan territory, with proviso for some pilgrimage rights and fishing net drying rights for Indian citizens and fishermen. While the subject continues to be of some political value in India, the peaceable manner in which India settled the dispute needs to be lauded and has important lessons for international community. This example amply displays India's reasonable approach to resolution of the Maritime boundary disputes.

\section{The future of Maritime Boundary Disputes}

Maritime boundary disputes have mostly become important and sensitive because of population pressures and quest for more wealth, making human interactions/interventions with oceanspace intense and complex. This has in turn resulted in unforeseen exogenous endogenous changes in the maritime domain. Generally changes deriving from resource pressures, international commodity prices, and new technologies could be termed as of exogenous category (for the oceans), driven by economic developmental needs.

On the other hand, changes due to rising sea levels and other oceanic changes resulting from climate change, and changing resource distributions, could come under the endogenous category to the maritime domain, with a specific geographic component. As a result, many disputes over maritime boundaries, access rights and interpretation of legal treaties or of UNCLOS have been left unresolved for decades. These are increasingly being brought up by various nations, at times even leading to direct clashes at sea between the involved states. This is quite applicable to Sir Creek dispute. 
Climate change and other environmental factors as well as population pressures have also created issues regarding fishing rights, forcing nations to explore options beyond 200 nautical miles of their continental shelves. Again, marine scholars like Osthagen (2020c) point out that:

The processes for determining the limits of continental shelves, beyond 200 nautical miles, have thus become increasingly relevant. As far as the high seas, many ongoing international negotiations to develop legal instruments for designating and managing Marine Protected Areas (MPAs), beyond national jurisdiction have borne fruits, albeit limited. New political challenges have thus been seen consequently emerging, as states hold differing views on access rights, marine environmental protection and exploitation and management of marine resources.

The situations as above affect the economic interests of the parties involved and also impact the wider ideas of symbolism and identity permeating into the political space where, even though a particular sea scape may lack economic value, holding on to the notion of dispute becomes necessary for playing into populist and electoral purposes. It is also not uncommon to observe that even settled issues like Kachathivu or emerging issues like South China Sea being referred to as discussions than disputes depending on the audience that the polity in concerned nations is playing to. In this regard, despite Kachathivu issue between India and Sri Lanka having been resolved, the rights of fishermen remaining a factor in Tamil Nadu politics validates such an observation.

\section{Part II: History of Sir Creek Dispute and it Importance for India}

\section{Fig 3: Sir Creek (Indicative map)}

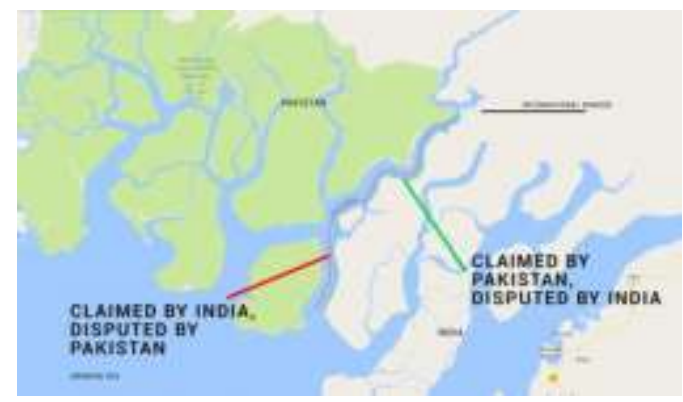

Source: Google

The Sir Creek (location coordinates 23 58N 68 48E) consists of 96-km strip (Fig: 3) of water. It can also be called a fluctuating tidal channel or an estuary situated in the marshes of Rann of Kutch, water from which flows into the Arabian Sea. It divides Kutch region in Gujrat state 
of India and the Sindh region of Pakistan. Originally named Ban Ganga, Sir Creek is named after a British representative involved in the dispute resolution process.

\section{History of Efforts for Resolution of Sir Creek Dispute: Resolution 1192 of 1914}

The dispute arose in 1907-1908, when the Maharao (Ruler) of Kutch claimed the part of Sindh lying east of the Green Line (a reference line which was drawn as a boundary line on the eastern bank of Sir Creek), as belonging to Kutch State shown in Figure 4 below:

Fig: 4 - Map B-44-Sir Creek ant the Vicinity

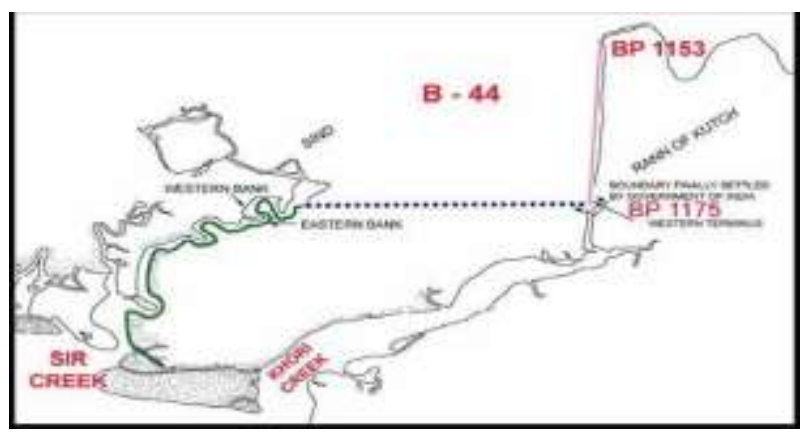

Source: Naval Post Graduate School, Monterey

The dispute originated when a group of wood cutters from Kutch area cut some trees in the Sindh area which was then part of the British Sindh territory. Explaining the details of the dispute and its resolution, Mohammad Ali (Ali, 2012a) states:

The matter precipitated as the commissioner of Sindh and Maharao of Kutch had differing opinions on territorial ownership of Sir Creek. During mediation, the then Government of Bombay sent a proposal to the Maharao of Kutch, agreeing to his claim that the boundary along the eastern bank of Sir Creek from the mouth to its top (shown as the green line on Map B-44, (Figure 7). It was also suggested by the Bombay government that the boundary should follow the east-west line from the top of the Sir Creek (shown as the blue dotted line) until it joins the Sindh boundary (the vertical purple line.) The Maharao of Kutch agreed to this proposal. Based on The Secretary of the Bombay Govt Letter \#5543, dated September 20, 1913, the government of India accorded the approval for the rectification of the boundary. Subsequently, the 
government of Bombay passed Resolution 1192 on February 24, 1914, approving the settlement by reference to Letter \#5543 along with Map B-44.

\section{Rann of Kutch Arbitration}

The settled Rann of Kutch territorial dispute once gain surfaced in the year 1947, shortly after the independence of both India and Pakistan. The cause was attributed to India claiming the entire area of the Rann of Kutch, while Pakistan insisted that the established boundary ran through the middle of the Rann or approximately along the 24th parallel. This was once again in line with the perceptive differences as has been discussed above.

Notwithstanding the 1948 Indo-Pak skirmish over accession of Kashmir which created acrimony on both sides, governments of India and Pakistan set about finding a solution to Sir Creek issue through negotiations. These negotiations continued till 1965. Matters came to a head when India accused Pakistan of armed patrolling in Sir Creek area along the $24^{\text {th }}$ Parallel.

India and Pakistan being part of the British Commonwealth, Prime Minister Harold Wilson of UK used his influence to bring both the countries to accept international arbitration to resolve the issue. At Britain's behest, United Nations appointed Gunnar Lagergren, a renowned Swedish Judge. Nasrollah Entezam (an Iranian diplomat and former President of the UN General Assembly) and Aleš Bebler, a Yugoslav diplomat and former President of UN Security Council were appointed as members, with the consent of both India and Pakistan. On February 19,1968 , the Tribunal by a majority agreement 90 percent of the disputed area of the Rann of Kutch to India and 10 percent to Pakistan (UN, 19 Feb 1968). Though it apparently set the issue to rest, certain portions of un-demarcated territories not included by India and Pakistan within the ambit of arbitral proceedings resulted in an impasse, and thus at the heart of Sir Creek dispute.

Gaurav Rajen (Rajen, 1999) also points to this by stating:

...unfortunately the Tribunal left the boundary of the Sir Creek un-demarcated because India and Pakistan had agreed not to refer this part of the un-demarcated boundary for arbitration to the tribunal. Presently, main reason of conflict has been whether the boundary lies on its east bank, as Pakistan claims or on the middle of the Sir Creek as 
India considers? An effective solution to this issue has eluded both India and Pakistan for almost 7 decades now.

Reflecting on the Arbitral Award, observers like Meena (Meena, 2016) further pointed out that:

The sole issue, therefore was, whether the short agreed boundary from the head of Sir Creek went all the way east or rose at a right angle at its western end to reach the northern limit of Rann. The tribunal accepted India's case that it did turn north and that almost the entire Rann was Indians. The dispute hinges on the demarcation of the boundary from "the mouth of his creek to the top of Sir Creek and from" the top of Sir Creek eastwards to a point designated as the western terminus. (Fig 5)

\section{Fig: 5 Representative Map of Sir Creek showing Western Terminus}

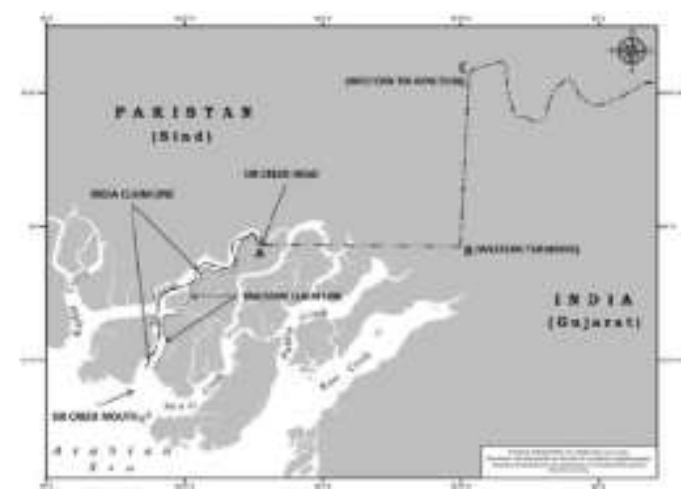

Image Courtesy: Reaserachgate.com

This issue has been analysed by other scholars like Mishra revealing a few important aspects complicating the sir Creek issue further (Mishra, Winter 2000-2001a):

Based on open sources, the geography of Sir Creek has changed to some extent since 1914 due to progressive and natural geo-physical effects. This has resulted in changes to the orientation of the Sir Creek meanders, and a large part of the boundary as marked on the 1914 map no longer matches the current on-ground location. Furthermore, the territorial as well as maritime dimensions of this dispute have been aggravated by Pakistan's 'Straight Baseline Claim' of August 29, 1996, which does not meet the provisions contained in Articles 5-11 and 13-14 of UNCLOS. In fact, the easternmost point of this baseline is located well south of the Sir Creek mouth. This has been challenged by India through its 2009 baseline Gazette notifications, by several other 
countries like the US and by legal experts dealing with Law of the Seas regime, in the absence of landlocked/shelf geography specified by Articles 69 and 70 .

It is thus seen that despite the arbitrational award going in favour of India, the dispute still remains unresolved due to perception differences between India and Pakistan.

This area has significant importance for India due to its direct bearing on India's territorial security and Govt. of India has been sensitive towards this matter. Govt. of India has consciously accorded a great importance to protection of India's maritime boundaries, including Sir Creek (GOI Report, Aug 2017). As per cited report:

India established a new Coast Guard Regional Headquarters (North West) in December 2009 to monitor and coordinate maritime security activities of the Gujarat coast. Three new Coast Guard stations were also set up, one each at Veraval, Mundra and Pipavav (closest to Sir Creek), for coordinating security issues with various stake holders. In addition, Indian Coast Guard has been deploying hovercrafts and Interceptor boats, in coordination with State Marine Police, for coastal patrolling in areas close to Indo-Pak maritime border.

Reports in the media (Hindu, 11 March 2020) also point to the possible oil and natural gas reserves in the area, thus indicating its strategic and economic value. If examined objectively, the differing perceptions over Sir Creek have a potential for reaching an amicable resolution as we would examine through some scholarly interpretations later.

To achieve this goal, as Joshi (Joshi, 16 Dec 2012) points out, it would be important to determine the maritime boundary between India and Pakistan based on the existing Rule of Law. Thus Pakistan would need to understand and appreciate the fact that the last point on the boundary, where the Creek touches during low tides, should be the beginning of the maritime boundary. This point is probably not acceptable to Pakistan as its orientation north or southwards adds or subtracts thousands of kilometres of the Oceanic shelf, supposed to be rich in fish/oil/natural gas reserves, thus withholding the resolution.

Persisting differences of opinion have not deterred India and Pakistan in continuing the efforts to settle the dispute thorough a series dialogues, albeit intermittent. The bilateral deliberations 
since 1969 have resulted in 12 rounds of talks without either side reaching any conclusion or compromise. The issue resulted in military tensions once again in 1999, after the Pakistan Navy's Maritime Patrol aircraft was shot down by an Indian MiG-21 fighter aircraft. However, the flare up was contained through high level discussions. The talks continued thereafter in 2012, in an atmosphere not so conducive to settlement.

Notwithstanding the length of pendency of this dispute, Sir Creek interestingly is not at the centre of strained Indo-Pak relations on account of the wars they have fought or the Pakistan assisted terrorism in Kashmir. Resolving Sir Creek within the framework of UNCLOS and the Arbitral Award has the potential therefore, to help thaw their disputes in other dimensions.

Having examined the historical background and the efforts made so far, we will look at some scholarly solutions and their possible implications.

\section{Part III: Possible Solutions and Implications for India}

The Indo-Pak differences in interpretation coupled with divergent technical opinions on the following points have become a major hurdle in resolution of the dispute:-

a) Approaches between from sea towards land and land towards sea

b) Linking of the Sir Creek boundary demarcation with the maritime boundary demarcation

These hurdles and provisions of UNCLOS have been studied by various maritime scholars with a view to find potential solutions. Three fold approach to the solutions recommended by the scholars include using joint survey to determine the extent to which the topography of Sir Creek area has changed over time to arrive at mutually acceptable boundary lines; delimitation of EEZ and Continental Shelf; using two undisputed referral points on shore to interpret the boundary by applying TALOS; and bringing the Sir Creek area under the purview of Ramsar Convention for Protection of Wetlands within the ambit UN Convention on Biological Diversity. The synopsis of solutions suggested by scholars merit consideration at this juncture:

\section{Solution 1}

Rear Admirals Vohra and Ansari (Vohra \& Ansari, 2003) point out that: 
A careful examination of the existing records would show that the boundary of Sir Creek was first established in1914, which could have changed due to the natural causes. It is, therefore, important to first survey and determine in reality how much Sir Creek has shifted due to accretion since 1914.

Post completion of such survey, India and Pakistan would need to holistically look at the following points, to arrive at an amicable agreement:-

a) 'British-Indian maps' prepared by the Surveyor General since 1914,

b) Maps formulating during the process of erecting pillars in 1924

c) Those maps which were prepared in 1947 at the time of Independence.

d) Sophisticated charts prepared during a recent survey of Sir Creek in 2007 that were subsequently exchanged

e) Exact location of Sir Creek as it presently exists.

Once above analysis phase has been completed and exact location of Sir Creek at the time of Independence in 1947 has been established, the situation could then be subjected to the recent decision made by the ICJ in 2005, in the case of Benin and Niger's maritime dispute. In this case the ICJ Chamber clearly defined the Niger River boundary by applying the 'Thalweg Principle' on status of the river that existed at the time of Independence in 1960. Thus, Pakistan and India should agree to ascertain the position of Sir Creek at the time of 1947 and subsequently resolve the matter using the above quoted decision of the ICJ as guiding principle.

\section{Solution 2}

It would also be seen that the United Nations Convention on International Law of the Sea (UNCLOS)-1982, have a provision to extend the jurisdiction of maritime states over adjoining seas. Articles 74 and 83 of UNCLOS describe the process of delimitation of the EEZ and the Continental Shelf. Resolution of maritime dispute between Suriname and Guyana (Ali, 2012b) is one of the empirical examples which could also be modelled to resolve the Sir Creek boundary dispute. 


\section{Solution 3}

To appreciate purport of 'Recommendation 3', it would be necessary to once again understand perceptions of India and Pakistan regarding demarcation of maritime boundary which has been clearly marked in Figure 8 (Ali, 2012c) (Shah, 2009)

\section{Figure 6: India \& Pakistan Perceptions -Sir Creek}

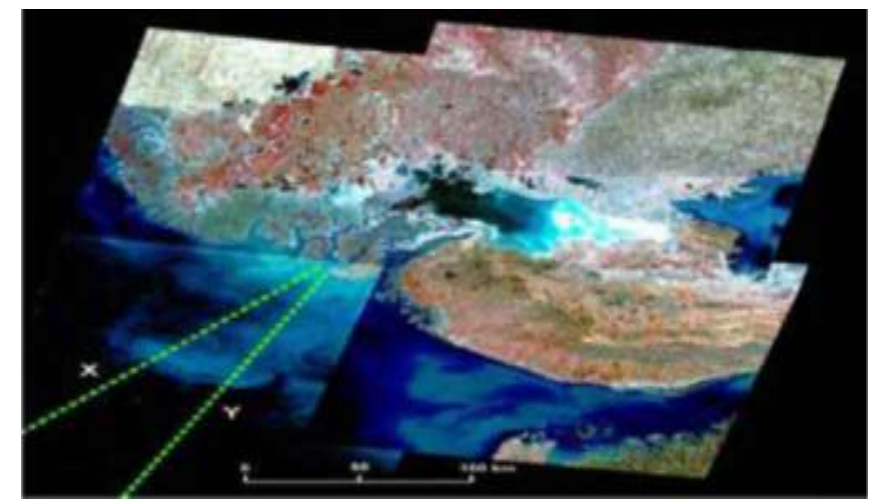

Figure Courtesy: Sandia National Laboratories

In the referred figure ( Figure:6) lines projected from Sir Creek show perceptions of India and Pakistan about the maritime boundary, in that Lines X and Y show India's and Pakistan's perceptions respectively.

It is feasible that (referring to the Figure above), the seaward approach in accordance with Technical Aspect on the Law of the Sea (TALOS) could be used as another method for resolution of the maritime boundary issue between two adjacent states.

This approach has also been recommended by Vohra and Ansari (Vohra and Ansari 2003b) by recommending that two undisputed shore points be marked from the mainland of India and Pakistan. Figure 7 illustrates this proposed solution.

Fig 7: Illustration of Equidistant Method 


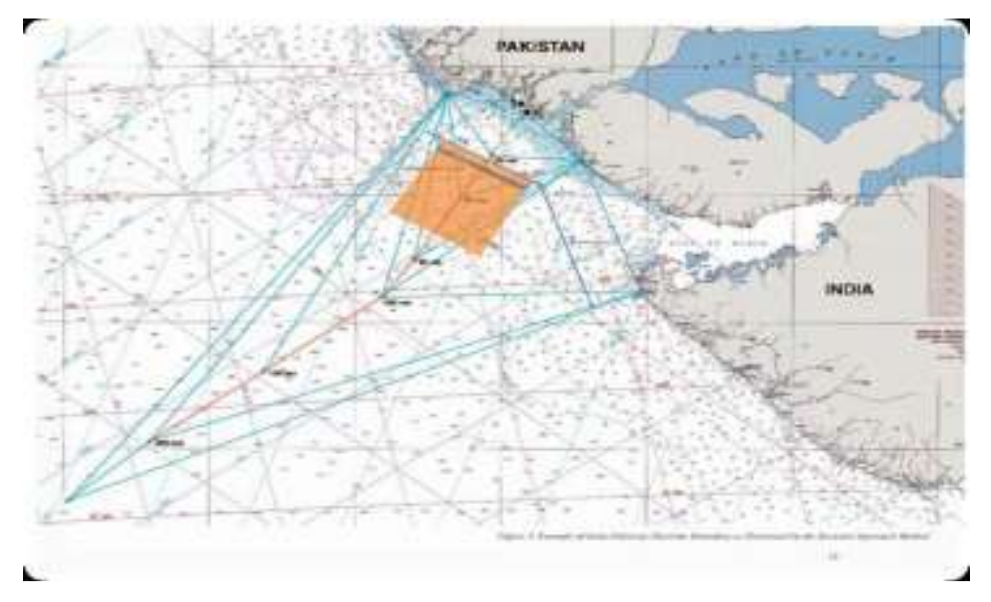

Image Courtesy: Sandia National Laboratories

Vohra and Ansari (2003c) further propose the following:

To find a mutually acceptable solution for the seemingly complex Sir Creek issue, a point of 200 nautical miles (the EEZ limit) could be determined, equidistant from already marked shore points on the respective mainland. Following the same procedure, other points at 150, 100, 50, and 35 nautical miles (Fig: 7) could be marked on the chart from the same mainland points. Moving further, a point could then be marked on the mouth of Sir Creek equidistant from the positions claimed by India (Point-1) and Pakistan (Point-K) as a solution without any bias to future claims. The line joining these points could be marked on chart and acknowledged by both the parties as the de-facto maritime boundary between Pakistan and India. This could offer a lasting solution to the problem.

\section{Solution 4}

Another school of thought has suggested that Sir Creek dispute should not be looked at as a Maritime Boundary dispute alone. Appreciating the significance of this region and acknowledging growing concerns of climate change impacting this vital ecosystem, this dispute could be reconfigured as an opportunity for joint environmental conservation and management. It is felt that reframing the Sir Creek dispute as an environmental matter may help in making questions related to demarcation less problematic. For adapting this approach many International mechanisms through wide-ranging environmental treaties are already available and could be used to ensure that the transboundary nature of ecosystems like Sir Creek be 
respected by involved states through joint conservation programs (Ali, 18 Dec 2017). Ali suggests that:

This dispute has an often-overlooked multilateral dimension that could provide an entry point for dispute resolution. Both countries are signatories to the U.N. Convention on Biological Diversity (CBD) as well as the Ramsar Convention on the Protection of Wetlands. Transboundary joint management and protection of these wetlands is part of the expected outcome of these conventions as well as the countries' obligations under the U.N. Convention on the Law of the Sea". Both countries need consider such innovative approaches.

Some other scholars have observed that interest in delimitation of a maritime boundary in this area has heightened in the recent years. Like Mishra (Mishra, Winter 2000-2001b) says: "This enhanced interest has been attributed to prospects of offshore oil and natural gas discovered in the area". The economic potential in the area has perhaps resulted in Pakistan hardening its stance by insisting on defining the extremity of its land frontier in the Sir Creek area, in a manner it desires. Its stance would apparently result in Pakistan expanding its EEZ by around 250 square miles. This of course needs acceptance by India at the Green Line showing Sir Creek's eastern bank (Fig-4) as the land boundary and then subsequently using equidistant line as the basis for the delimitation of the maritime boundary. India's stance on the hand, calls for acceptance of Mid-Channel Principle which is more logical and amply supported by international case laws (as in Sidra). Pakistan contends that the Mid-Channel Principle applies only to navigable channels and points to the non-navigable nature of Sir Creek. This argument is neither acceptable to India nor is supported by international law.

India is also firmly against Pakistan's bid to internationalise the Sir Creek issue. India has rightly points to the 'Shimla Accord' which offers a credible way for bilateral resolution of differences. However, Pakistan's insistence for internationalizing the issue and its unrelenting attitude has led both sides away from a potential compromise.

It is, therefore, important that India uses UNCLOS, globally acceptable boundary demarcation principles, diplomacy and help from friendly nations to bear pressure on Pakistan to accept the reasonable proposition made by India. 
Finally, fact remains that India needs to ensure that all the options to settle this dispute are explored and an agreement reached on fast track, to avoid interference from China using Belt and Road Initiative (BRI) as a lever to topple the process, for its own gains.

\section{Part IV: Potential Chinese interest in Sir Creek Dispute}

Analysis has revealed that China's Belt and Road initiative (BRI) has an open-hidden agenda of reopening ancient trade routes around the world, once known as the Silk Roads. China's own mouth piece, Belt and Road Initiative News (BRI News 2020) has stated: "Indeed, the stateowned investment arm overseeing a range of the $\$ 1$ trillion BRI's trade-promoting infrastructure projects is known as the Silk Road Fund".

BRI's public relations materials also frequently point to a supposed Southern Silk Road, a trade route that reportedly originated in China's southern Sichuan and wound through present-day Myanmar on to the Bay of Bengal and Indian subcontinent. That historically dubious trade route has been further embellished by a supposed ocean-spanning Maritime Silk Road, which passed through the Indian Ocean during an unspecified period in history. This has helped Beijing to soft-sell its otherwise controversial BRI concept, now under rising criticism for causing sovereignty-eroding debt traps in recipient nations, to a wider global audience.

Another important component of the BRI's Southern Silk Road is the envisioned Bangladesh India-Myanmar-Economic Corridor. Myanmar happens to be in the middle of Beijing's New Silk Road. China's Vision for that supposedly old Southern Silk Road had plans for high speed railroads, highways and a deep-sea port. However, such big ticket schemes had to be scaled back due to overall concerns related to debt trap diplomacy.

Like the original Silk Road, Xi's BRI is driving rivalries for control of valuable trade routes, pitting China against the United States, European Union, India, Japan and others that seek to resist Beijing's rising hegemony.

Another matter of bigger concern for India, is the China- Pakistan Economic Corridor (CPEC), which more credibly runs along ancient Silk Road Routes, connecting the north western Chinese province of Xinjiang to Pakistan's port of Gwadar on the Arabian Sea. Sir Creek and the disputed maritime domains could become critical for Chinese Maritime Silk Road interests in the Arabian Sea for its obvious proximity to Iran from where China procures its oil needs. It 
could also pose challenges to China for its natural gas acquisitions from Central Asia, for Gwadar presents an opportunity for cutting logistic overheads in transporting these resources to mainland China.

Playing the Sir Creek card either way, China appears to benefit from keeping the dispute alive to up its pressure on India or alternatively, gain from having it resolved in favour of Pakistan. This could be a problem for Sir Creek area and may also potentially raise the tensions in the Arabian Sea region.

It is also important to note that given current geo-political situation between India and China, India's growing stature with ASEAN and BIMSTEC countries as well as QUAD, China may turn the Indo-Pak Sir Creek bilateral dispute into a multilateral dispute as an arm twisting technique.

The above narrative should serve as a wakeup call for India to resolve the Sir Creek dispute on priority and build good neighbourly relationships with the countries in the South East Asian Region. The narrative also places India in conflict with the China's ambitions and emphasises the need for proactive actions by India not only in IOR but also in the Indo-Pacific region which includes the South China Sea.

\section{Part V: Conclusion and Recommendations}

Sir Creek would always be strategically, economically as well as in the environmental dimension important for India, even outside the bona fide historical claims it has over it. Apart from its border related strategic implications, the economic and energy security value of this region has increased manifold as a result of studies conducted by National Institute of Oceanography Goa (NIO), Oil and Natural Gas Commission (ONGC) and private agencies like Essar and Cairn. Vijayalakshmi Nair of the NIO Regional Centre Kochi (Nair, 2002) for example, points out the rich biodiversity of mangroves, flora $\&$ fauna and fish varieties in the Gulf of Kutch. Vikas Srivastava (Srivastava, 2017) of the Financial Express reported that ONGC had made 17 discoveries in the Gulf of Kutch and has planned to commence physical production of around 30 million metric tonnes by 2020. In the adjoining Gulf of Cambay, private player Cairn has already struck oil and gas, as per a report filed by Pradeep Puri (Puri, 2013) for the Business Standard. 
India faced one of the most ignominious terrorist attacks on November 26, 2008 on its port city of Mumbai. The attack came from the sea, aided by Pakistan's navy and caught India virtually unawares. The attack is an important pointer since India's maritime and energy security interests have furthered in the last decade. India has at least five ports in the region and one of Asia's biggest oil refineries in the region. Hence, in the geostrategic dimension, with its energy security and livelihood interests now involved across the Rann of Kutch in the Gulf of Kutch, India needs to re-visit and re-appraise its options for settling the decades old Sir Creek maritime boundary issue.

China's involvement in Pakistan through CPEC and its apparent strategic interests in the Arabian Sea (as discussed earlier) lend no small sense of urgency to this, in our opinion.

It is therefore important that India uses UNCLOS and its globally acceptable boundary demarcation principles together with focused diplomacy with friendly nations to bear pressure on Pakistan to accept the reasonable proposition made by India. The remarkable bonhomie that defines India's relations with USA as well as its longstanding, deep rooted relations with Russia especially need to be leveraged in this regard. India's recent efforts to strengthen its ties with Gulf Countries should also be invoked to arrive at a settlement within the ambit of international law.

India needs to ensure that all the options including CBD available to settle this dispute are explored and an agreement reached on fast track, to avoid interference from China using Belt and Road Initiative (BRI) as a lever to topple the process for its own gains. Following measures could help India in keeping the Dragon in check:

- Strengthen its relations with ASEAN through constructive political, economic and military engagements with Southeast Asian nations

- Strengthen BIMSTEC alliances by cultural, economic and political engagement

- Improve the efficacy of QUAD by engaging with its partners, carefully balancing its own strategic interests in IOR

- Put measures in place to reduce the internal turmoil, build consensus for conducive political atmosphere and revive the economy on fast track

Assuming a best case scenario that by using all that is available at hand (to resolve the Sir Creek dispute), India manages to achieve a favourable settlement, an interesting question pops up as 
to whether China will pressurise Pakistan to junk the settlement, as China itself has done in case of Philippines, to further its own ends? India must keep this question in mind while pursuing the early settlement of this dispute.

There are some other lingering questions for which we have not attempted any answer, but finding answer to which may also be relevant in the light of emerging international order:

a) Post Presidential Elections in Dec 2020 in USA, what scenario India would need to face? What would be the impact on USA-Pakistan and Indo-Pakistan relations? This question arises because of the political turmoil in USA that has presented a very confusing scenario.

b) How Pakistan would react to all the initiatives taken by India to resolve the dispute, as they would have a direct impact on geopolitical and economic situation of Pakistan, its troubled relationship with many nations including USA and debt entrenched relationship with China.

We do hope the pundits across the spectrum would attempt to evaluate these questions and find workable solutions.

\section{Acknowledgment}

The author would like put on record his thanks to MPIDSA for valuable article support; Dr R Srinivasan for timely guidance, revisions and additions; Dr BN Jajoo and Dr VL Joshi (former professors from College of Engineering, Amravati, Maharashtra) for their valuable guidance and Ms Sujata Deshmukh for constant motivation and excellent logistical support.

\section{References:}

Guo, R. (2018a). Cross-Border Resource Management. Elsevier. https://doi.org/10.1016/C2016-0-04674-0. (Accessed 28/29 September 2020).

TFS (2017). Tufts University, Chapter 6- Maritime Boundaries, Laws of The Sea, retrieved from https://sites.tufts.edu/lawofthesea/chapter-ten/ (Accessed on 08 Oct 2020)

TFS (n.d), Tufts University, Chapter 10- The South China Sea Tribunal. Laws of the Sea - A policy primer, retrieved from https://sites.tufts.edu/lawofthesea/chapter-ten/ (Accessed on 08 Oct 2020)

Østhagen, A (2020a). Maritime boundary disputes: What are they and why do they matter? Marine Policy, 120, 104-118. Retrieved from: 
https://www.sciencedirect.com/science/article/pii/S0308597X20302426 (Accessed 28/29 September 2020).

UNCTAD (n.d). UNCTAD | Oceans Economy and Fisheries. Retrieved from https://unctad.org/en/Pages/DITC/Trade-and-Environment/Oceans-Economy.aspx. (Accessed 04 October 2020).

Hasan, M. M., Jian, H., Alam, M. W., \& Chowdhury, K. M. A. (2019). Protracted maritime boundary disputes and maritime laws. Journal of International Maritime Safety, Environmental Affairs, and Shipping, 2(2), 89-96. https://doi.org/10.1080/25725084.2018.1564184 (Accessed 04 October 2020).

Guo, R. (2018b). Chapter 12-Cross-Border Conflict Prevention and Management*. In R. Guo (Ed.), Cross-Border Resource Management (Third Edition) (pp. 337-386). Elsevier. https://doi.org/10.1016/B978-0-444-64002-4.00012-X (Accessed 28/29 September 2020).

Østhagen, A. (2020b \& c). Maritime boundary disputes: What are they and why do they matter? Marine Policy, 120, 104-118.. https://www.sciencedirect.com/science/article/pii/S0308597X20302426 (Accessed 28/29 September 2020).

Ali, Muhammad (Dec 2012a). Maritime Issues between Pakistan and India: Seeking Cooperation and Regional Stability, Naval Post Graduate School, Monterey: Cal, Pp 14-20. Retrieved from: www.hsdl.org (Accessed on: 20-21 Oct 2020).

UN (19 Feb 1968). The Indo-Pakistan Western Boundary (Rann of Kutch) between India and Pakistan (India, Pakistan), Volume XVII pp. 1-576. See for full text: https://legal.un.org/riaa/cases/vol_XVII/1-576.pdf (Accessed 15 January 2021).

Rajen, G. (1999). An Indian and Pakistani CBM: The Sir Creek Trans-Border Area. The New Security Debate, 1, 49-50. https://www.peacepalacelibrary.nl/ebooks/files/UNIDIR_pdfart267.pdf (Accessed 13 October 2020)

Meena, C.M, Dr (11 Dec 2016). The Geopolitics of Sir Creek: An Evolution, IJRARInternational Journal of Research and Analytical Reviews, Vol. 3 Issue 4, Oct-Dec. 2016, P 97. Retrieved from: http://ijrar.com/upload_issue/ijrar_issue_387.pdf (Accessed 28 October 2020)

Misra, A. (2000, Winter 2000-2001a). The Sir Creek Boundary Dispute: A Victim of IndiaPakistan Linkage Politics. IBRU: Centre for Borders Research : Publication - Durham University. https://www.dur.ac.uk/ibru/publications/view/?id=177 (Accessed on 12 Oct 2020)

GOI Report- Committee on External Affairs 2016-17 (Aug 2017). Lok Sabha Secretariat, Indo-Pak Relations, Retrieved from http://164.100.47.193/lsscommittee/External\%20Affairs/16_External_Affairs_16.pdf, (Accessed on 10 Oct 2020) 
The Hindu (11 Mar 2020). The Hindu, Explained: Sir Creek Dispute, Retrieved from: https://www.civilsdaily.com/news/explained-sir-creek-dispute/ (Accessed on 08 Oct 2020)

Joshi M, (16 Dec 2012), Times of India, The troubled water for Sir Creek, Retrieved from: https://www.indiatoday.in/india/north/story/sir-creek-dispute-gujarat-chief-minister-narendramod-rann-of-kutchmaritime-boundary-124418-2012-12-16 (Accessed on 20-21 Oct 2020).

Vohra R and Ansari H (Dec, 2003a). Confidence Building Measures at Sea: Opportunities for India and Pakistan, Sandia National Laboratories (Occasional Paper), Retrieved from https://www.sandia.gov/cooperative-monitoring center/_assets/documents/sand2004-0102.pdf (Accessed on 10 Jan 2021)

Ali, Muhammad (Dec 2012b \& c). Maritime Issues between Pakistan and India: Seeking Cooperation and Regional Stability, Naval Post Graduate School, Monterey: Cal, Pp 14-20. Retrieved from: www.hsdl.org (Accessed on: 20-21 Oct 2020)

Shah, Sikander A (2009). River Boundary Delimitation and the Resolution of the Sir Creek Dispute between Pakistan and India, Vermont Law Review, Vol. 34:357. Retrieved from: http://docplayer.net/59851886-River-boundary-delimitation-and-the-resolution-of-the-sircreek-dispute-between-pakistan-and-india.html (Accessed on 25 Dec 2020 and 11 Jan 2021)

Vohra, R and Ansari, H (Dec, 2003b \& c). Confidence Building Measures at Sea: Opportunities for India and Pakistan, Sandia National Laboratories (Occasional Paper), Retrieved from https://www.sandia.gov/cooperative-monitoring center/_assets/documents/sand2004-0102.pdf (Accessed on 10 Jan 2021)

Ali Saleem H (18 Dec 2017a). Use Environmental Diplomacy to resolve Sir Creek Dispute, Stimson Centre. Retrieved from: https://www.stimson.org/2017/use-environmentaldiplomacy- (Accessed on 28 Oct 2020 and 11 Jan 2021)

Misra, A. (2000, Winter-2001b). The Sir Creek Boundary Dispute: A Victim of IndiaPakistan Linkage Politics. IBRU: Centre for Borders Research : Publication - Durham University. https://www.dur.ac.uk/ibru/publications/view/?id=177 (Accessed on 12 Oct 2020).

Belt and Road News (30 Nov 2019b). beltandroad.news. Retrieved from: www.belrandroad,news/2019/11/30/chinas-belt-road-resume-ancient-trade-routes-as-silkroads/ (Accessed on 12 Oct 2020).

Nair, Vijayalakshmi (March 2002). Status of the Flora and Fauna of Gulf of Kachchh India, National Institute of Oceanography Regional Centre: Kochi, Pp 1-144. See: http://drs.nio.org/drs/bitstream/handle/2264/87/TOC\%20and\%20Introduction.pdf?sequence= 1\&isAllowed=y (Accessed 12 Jan 2021).

Srivastava, Vikas (27 June 2017). ONGC aims to start production from Gulf of Kutch basin by 2020, The Financial Express (online). See: 
https://www.financialexpress.com/industry/ongc-aims-to-start-production-from-gulf-of-kutchbasin-by-2020/736908/ (Accessed 13 Jan 2021).

Puri, Pradeep (January 27, 2013). Cairn Finds Gas in Gulf of Cambay, the Business Standard (online). See: https://www.business-standard.com/article/specials/cairn-finds-gas-in-gulf-ofcambay-100051701053_1.html (Accessed 13 Jan 2021).

\section{Additional References that may be of interest to scholars:}

Dabas, M. (2016, August 16). Everything You Need To Know About The Dispute Over Sir Creek Between India And Pakistan. India Times.

https://www.indiatimes.com/news/everything-you-need-to-know-about-the-dispute-over-sircreek-between-india-and-pakistan-260071.html.

Garner JW (12 Apr 2017). The Doctrine of Thalweg as a Rukle of International Law, Cambridge University Press, Retrieved from:

https://www.cambridge.org/core/journals/american-journal-of-internationallaw/article/doctrine-of-the-thalweg-as-a-rule-of-internationallaw/BB01697893ED492376AE3DA9C887FC45

Joshi M, (16 Dec 2012), Times of India, The troubled water for Sir Creek, Retrieved from: https://www.indiatoday.in/india/north/story/sir-creek-dispute-gujarat-chief-minister-narendramod-rann-of-kutchmaritime-boundary-124418-2012-12-16

Smith, J., M. (2018, March 14). Unpacking the Free and Open Indo-Pacific. War on the Rocks. https://warontherocks.com/2018/03/unpacking-the-free-and-open-indo-pacific/. 